\title{
Cervical Cancer Clinical Distant Metastasis TNM Finding v8
}

National Cancer Institute

\section{Source}

National Cancer Institute. Cervical Cancer Clinical Distant Metastasis TNM Finding v8. NCI Thesaurus. Code C139684.

A clinical finding about one or more characteristics of cervical cancer, following the rules of the TNM AJCC v8 classification system as they pertain to distant metastases. 